\title{
DATA AVAILABLE ON CD-ROM
}

UNIDO maintains several databases on industrial statistics, of which new sales versions are made available annually.

INDSTAT2: UNIDO

Industrial Statistics Database at the 2-digit level of ISIC code (Revision 3)
Long time series for 163 countries/areas compiled on eight principle indicators (number of establishments, total employment, female employment, wages and salaries paid to employees, output, value added, gross fixed capital formation and index numbers of industrial production) starting from 1963 onwards. The data are arranged at the 2-digit level of ISIC (Revision 3) pertaining to the manufacturing sector, which comprises 23 manufacturing divisions.

All value data are originally stored in national currency values at current prices. The system allows for data conversion from national currency into current U.S. dollars.

Time series data for 127 countries/areas on seven selected data items including number of establishments, total employment, female employment, wages and salaries paid to employees, output, value added and gross fixed capital formation starting from 1990 onwards. The data are arranged at the 3- and 4-digit level of ISIC (Revision 3) pertaining to the manufacturing sector, which comprises 151 manufacturing industries.

All value data are originally stored in national currency values at current prices. The system allows for data conversion from national currency into current U.S. dollars.
IDSB: UNIDO Industrial Demand-Supply Balance Database at the 4-digit level of ISIC code (Revision 3)
Time series (starting from 1990) for more than 85 countries on output, imports, exports and apparent consumption (all in current US dollars) at the 4-digit level of ISIC (Revision 3).

Further details on above products may be obtained from:

Statistics Unit, UNIDO

P.O. Box 300

A-1400 Vienna, Austria

Fax: (+43-1) 26026-6802

Email: stat@unido.org

Internet: http://www.unido.org/statistics 
UNIDO - 9781781002414

Downloaded from PubFactory at 04/26/2023 02:05:11AM via free access 